\title{
The role of gastrointestinal hormones in the pathogenesis of obesity and type 2 diabetes
}

\author{
Edyta Adamska ${ }^{1}$, Lucyna Ostrowska², Maria Górska3 ${ }^{3}$, Adam Krętowski ${ }^{1,3}$ \\ ${ }^{1}$ Centre for Clinical Research, Medical University of Bialystok, Poland \\ 2Department of Dietetics and Clinical Nutrition, Medical University of Bialystok, Poland \\ ${ }^{3}$ Department of Endocrinology, Diabetology and Internal Medicine, Medical University of Bialystok, Poland
}

Prz Gastroenterol 2014; 9 (2): 69-76

DOI: $10.5114 / p g .2014 .42498$

Key words: gut hormones, obesity, diabetes.

Address for correspondence: Edyta Adamska MD, Centre for Clinical Research, Medical University of Bialystok,

24a M. Sklodowskiej-Cure St, 15-276 Bialystok, Poland, phone: +48 693726 228, e-mail: edyta.adamska@umb.edu.pl

\begin{abstract}
Obesity, influencing the increase of incidence of type 2 diabetes, cardiovascular complications and cancer is a growing medical problem worldwide. The feelings of hunger and satiety are stimulated by the "gut-brain axis", where a crucial role is played by gastrointestinal hormones: glucagon-like peptide 1, glucose-dependent insulinotropic polypeptide, pancreatic polypeptide, peptide YY, oxyntomodulin, cholecystokinin and ghrelin. These hormones affect not only the functioning of the digestive tract, but also might have effects on insulin secretion and are mediators which affect brain areas involved in the regulation of food intake. The effect of their actions can be antagonistic as well as an additive or synergistic, and their secretion is dependent on many factors, such as dietary nutrients or the energy state of the body. Changes in circulating gut hormones concentrations result in activation of various pathways primarily within the hypothalamus and brain stem areas, which modulate feeding behaviour and a number of metabolic processes.
\end{abstract}

\section{Brain - gut axis regulation}

The central nervous system (CNS) (the paraventricular nucleus and the hypothalamic arcuate nucleus), which receives signals from the alimentary tract as well as from adipose tissue, plays a key role in the body's energy balance. The feelings of hunger and satiety are regulated in the CNS via the brain-gut axis, with a number of hormones playing critical roles (Table I). Ghrelin is the main and, as it seems, the only known appetite-stimulating gastrointestinal hormone. Its levels increase with fasting and stimulate food intake via the vagus nerve, the brainstem and the hypothalamic arcuate nucleus; whereas satiety-stimulating hormones such as pancreatic polypeptide (PP), peptide YY (PYY), oxyntomodulin (OXM), cholecystokinin (CCK) and glucagon-like peptide-1 (GLP-1) are released during eating (Figure 1) [1-6]. Some of these hormones also affect insulin secretion. Glucagon-like peptide-1 and glucose-dependent insulinotropic peptide (GIP) are hormones that stimulate postprandial insulin secretion.

\section{Gastrointestinal hormones affecting hunger/satiety}

\section{Ghrelin}

Ghrelin, also known as "the hunger hormone", produced in the so-called X/A-like endocrine cells of the gastric fundus, is the only known appetite-stimulating gastrointestinal hormone [7]. Ghrelin is recognized as a meal-initiating hormone. Its levels are increased after overnight fasting, they rise approximately two-fold immediately before a meal and decrease to their lowest values $1 \mathrm{~h}$ after each meal (Figure 2) [8,9]. Postprandial decrease of ghrelin levels is further dependent on meal calorie value and composition; for example, the decrease is lower after fat-based meals compared with carbohydrate- or protein-based meals [10, 11]. Basic ghrelin levels respond in a compensatory manner to the energy deficit/excess: low ghrelin levels are observed in obesity, whereas high levels in anorexia (Figure 2) $[12,13]$. A lower decrease in ghrelin levels in relation 
Table I. The main mechanisms of action of gut hormones and "adiposity signals" (modified according to Suzuki et al. Endocr J 2010) [6]

\begin{tabular}{ll} 
& Gastrointestinal hormones - "satiety signals" regulating the beginning, end and intervals between meals \\
\hline GLP-1 & Incretin effect, satiety regulation, delayed gastric emptying \\
\hline GLP-2 & Affects gastrointestinal motility and trophic effect in the intestinal tract \\
\hline Ghrelin & Hunger stimulation \\
\hline PYY & Satiety regulation, delayed gastric emptying \\
\hline PP & Affects gastric motility, satiety regulation \\
\hline OXM & Satiety regulation, affects HCl secretion, incretin properties \\
\hline CCK & Affects gastrointestinal motility, exocrine pancreatic enzyme secretion, secretory \\
\hline GIP & function of the gallbladder \\
\hline Amylin & Incretin effect \\
\hline & Affects glucose homeostasis, gastric motility \\
\hline Insulin & "Adiposity signal" hormones - role in regulating the formation of energy reserves \\
\hline Leptin & Affects glucose homeostasis, glycogen synthesis \\
\hline
\end{tabular}

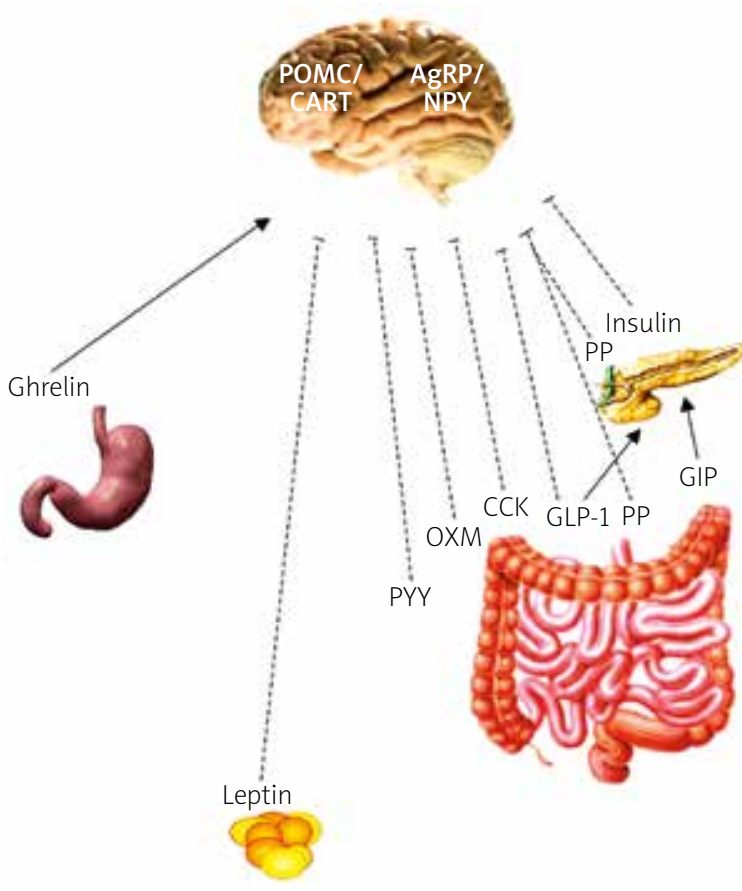

Figure 1. Hunger/satiety regulation in CNS ("gut-brain axis")

--- anorectic effect, $\rightarrow$ orexigenic/stimulatory effect, NPY - neuropeptide Y, AgRP - Agouti-related peptide, POMC - proopiomelanocortin, CART - cocaine- and amphetamine-regulated transcript, GLP-1 - glucagon-like peptide-1, GIP - glucosedependent insulinotropic peptide, PP - pancreatic polypeptide, PYY - peptide YY, OXM - oxyntomodulin

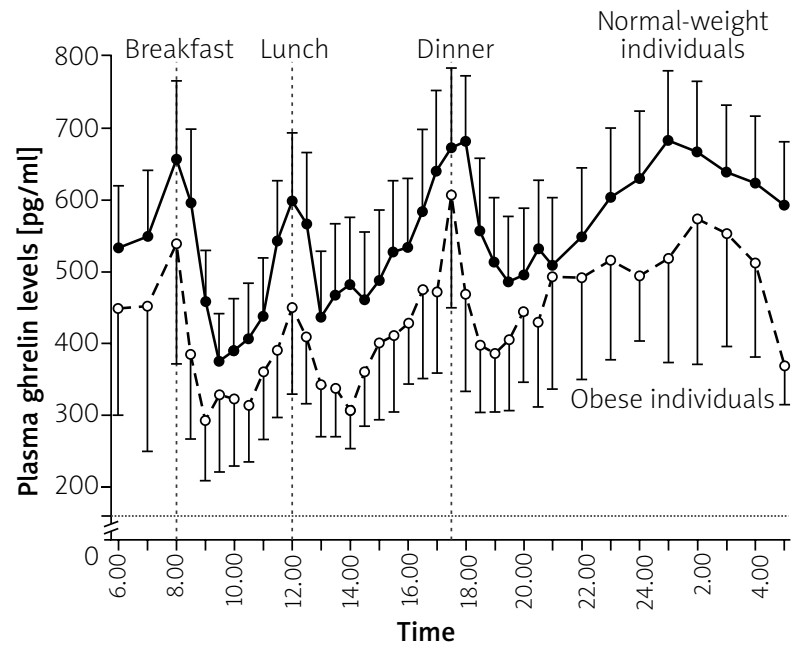

Figure 2. Mean 24-hour plasma ghrelin profiles in normal-weight and obese subjects (modified by Cummings et al. NEJM 2002) [9]

to fasting values is observed in postprandial obese individuals [14].

Ghrelin is acylated at position 3 into an active, acylated form that can pass the blood-brain barrier and bind to a receptor that stimulates growth hormone (GH) secretion. In the CNS, ghrelin stimulates hypothalamic production of neuropeptide Y (NPY) and Agouti protein (AgRP) by influencing mitochondrial uncoupling proteins (UCP2) [15-17]. Acylated ghrelin neutralization reduces food intake and leads to weight-loss in diet-induced obese mice [18]. Long-term ghrelin administration in experimental animals leads to weight gain, resulting from hyperphagia, and increased expression 
of enzymes that promote fat accumulation in the adipocytes [19].

\section{Cholecystokinin}

Cholecystokinin (CCK) was the first gastrointestinal hormone found to act as a hunger suppressant [20]. Cholecystokinin is mainly produced in the L-cells of the duodenum and small intestine [21] in response to a meal, to stimulate pancreatic hormone secretion, bile secretion [22] and inhibition of gastric emptying [23]. An increase in CCK blood levels is observed approximately $15 \mathrm{~min}$ after meal initiation [22]. Therapeutic use of CCK is restrained due to its 1-2-minute half-life. Administering CCK earlier than $15 \mathrm{~min}$ before a meal does not result in meal size reduction [20].

There are several known bioactive forms of CCK, such as CCK-8, CCK-22, CCK-33 and CCK-58, which differ in the number of amino acids. Cholecystokinin-33 is the prevailing form found in plasma and the intestines [24]. Cholecystokinin is widely distributed in the CNS, including the hypothalamus, where it is most abundantly present in the dorsomedial nucleus and the median eminence of the hypothalamus [25].

Two types of CCK receptors, CCKA and CCKB, are known $[26,27]$. CCKA (also known as CCK1) seems to play a more important role in food intake regulation. Administering selective antagonists for this receptor in experimental animals abolishes the inhibitory effects of intraperitoneal CCK-8 infusion [28]. Rats, lacking CCKA expression (Otsuka Long Evans Tokushima Fatty Rats), present with high food intake, obesity and hyperglycaemia [29]. However, studies in knockout mice do not confirm long-term effects on body weight [30]. CCKA receptors are expressed in the pancreas, afferent and efferent neurons of the vagus nerve, the nucleus of the solitary tract (NTS), the area postrema and the hypothalamic dorsomedial nucleus, which are the key regions regulating food intake [26].

The influence of exogenous CCK on the reduction of food intake is hormone-dose dependent, both in rats [20] and in humans [31].

Gastric or abdominal vagotomy abolishes the effect of satiety induced by CCK-8 administered peripherally, indicating that vagus nerve CCKA receptors may play a crucial role in food intake regulation [32]. Peripheral CCK administration decreases food intake by reducing meal duration as well as the quantity of the ingested food [31]. It was shown that CCK administered in high doses causes nausea and taste aversion [33-35]. However, the anorectic effect of low doses and malaise in experimental animals are not correlated [36]. Centrally administrated CCK also decreases food intake, and the effect is potentiated by concomitant administration of leptin. CCK, along with leptin, is likely to play an important role in long-term weight regulation [37].

Studies on the use of CCK in obesity treatment showed that intermittent infusions of CCK for 6 days reduces ingested meal size by at least $44 \%$; however, it increases meal frequency by $162 \%$ or more, but with no effect on body weight [38]. Furthermore, it was shown that a 2-week continuous intraperitoneal CCK infusion resulted in the rapid development of tolerance, and thus a lack of effect on food intake or body weight [39].

Studies show that in lean individuals the increase in postprandial CCK levels is high and fast, which may result in earlier occurrence of satiety, while in obese individuals, postprandial CCK levels remain increased for longer [40]. Postprandial CCK levels may also be sexand meal composition-dependent. Higher CCK levels are observed after high-fat meal ingestion. The increase of CCK levels is higher in females [41].

\section{Peptide YY}

Peptide YY is a 36-amino-acid protein with NPY and pancreatic hormone-like structure, produced in the gastrointestinal L-cells, mainly in the colon and rectum. Its name derives from two tyrosine molecules $(Y)$ at the initial and terminal portion of the peptide. The PYY3-36 fragment, which is an active form, is mainly detected in peripheral circulation [42, 43].

The physiological role of PYY is associated with the meal "termination" signal; PYY levels are low after overnight fasting, at their highest in the $2^{\text {nd }} \mathrm{h}$ after meal initiation and gradually decreas within $6 \mathrm{~h}$ from reaching their highest value. Peptide $Y Y$ acts mainly via the $Y 2 R$ receptor in neurons producing NPY in the hypothalamic arcuate nucleus [42, 44].

Peptide YY shows "satiety peptide" properties. Previous studies reveal low PYY levels in obese patients [45]. Peripheral administration of PYY to humans results in a $30 \%$ or higher reduction in the calorific value of a meal consumed $2 \mathrm{~h}$ after PYY infusion and a 33\% reduction in the quantity of consumed food over $24 \mathrm{~h}$ [44, 45]. Postprandial PYY peak further depends on meal calorie value and food composition (Figure 3) [46].

\section{Pancreatic polypeptide}

The pancreatic polypeptide (PP) is a peptide secreted by PP cells in the islets of Langerhans and, in smaller amounts, by colon and rectum cells. It acts through the $Y$ receptors, particularly $Y 4$ and $Y 5[47,48]$. Pancreatic polypeptide does not pass through the blood-brain barrier, but it affects the CNS via Y receptor activation in the area postrema of the brain stem with high expression of the Y5 receptor (where the "tight" blood-brain 


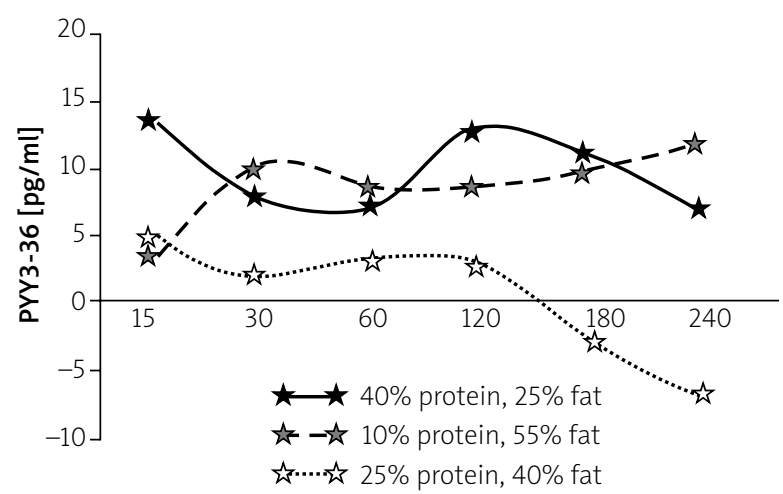

Figure 3. Changes in plasma PYY3-36 concentration after ingestion meals with varying content of protein/fat/carbohydrate (by El Khoury et al. Eur J Nutr 2010) [46]

barrier is absent) [49]. Although food intake stimulation using $\mathrm{Y} 5$ receptor agonists was lower in $\mathrm{Y} 5-/-$ knockout mice [50], it remained unaltered in a nonsense model of limited $Y 5$ signalization [51].

Fasting PP levels are low, but their postprandial levels increase and are correlated with meal calorie value. Pancreatic polypeptide was also observed to reduce gastric emptying [52]. Studies in animals show that the pancreatic polypeptide's effects on food intake regulation depend on the activated receptor location, and may be different depending on the site of hormone administration. Peripheral PP administration reduces food intake by $11 \%$ [53] or even by $22 \%$ (the effect lasts up to 24 h) [54], whereas direct CNS receptor stimulation (intraventricular PP administration) increases food intake in experimental animals [55]. Peripheral PP administration in genetically obese (ob/ob) mice, which do not secrete leptin and lack PP cells in the pancreas, reduces food intake and body weight [56].

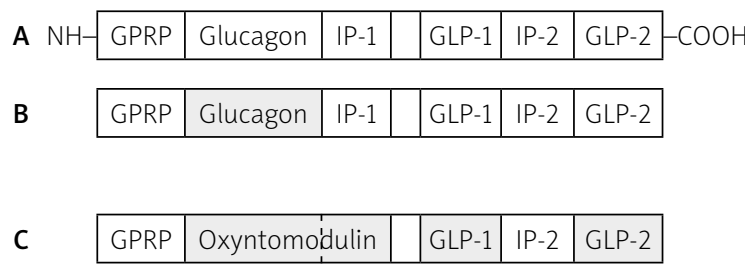

Figure 4. Post-translational products of proglucagon: A - proglucagon; $\mathbf{B}$ - products of alternative splicing in pancreas; $\mathbf{C}$ - products of alternative splicing in intestine and brain (by Kieffer et al. Endocr Rev 1999) [69]

\section{Oxyntomodulin}

The name 'oxyntomodulin' (OXM) derives from its function to modulate the gastric oxyntic glands producing $\mathrm{HCl}$. Oxyntomodulin is secreted by the L-cells, depending on the calorie value of the ingested meal, in parallel with GLP-1 production, and has an influence on the GLP-1 receptor in the hypothalamic arcuate nucleus $[57,58]$. Oxyntomodulin, which has a 50-fold lower affinity for receptor GLP-1R, compared with GLP-1 [59], also shows effects independent of the receptor stimulation (an OXM-specific receptor has not been identified so far). As with GLP-1, OXM is also inactivated by the DPP-IV enzyme [60].

Oxyntomodulin shows an incretin effect as well as $\beta$-cell protective properties [61]. Studies have revealed that in healthy individuals oxyntomodulin reduced appetite and the amount of ingested food by $19.3 \%$ [62], and in obese individuals it reduced body weight by $2.3 \mathrm{~kg}$ in 4 weeks [63] and increased energy expenditure by $9.4 \%$ (as opposed to most weight loss treatments) [64]. It has been shown that the appetite suppressing effects of OXM are partly due to the inhibition of ghrelin secretion (a decrease in secretion by $44 \%$ after IV infusion of OXM) [62]. A reduction in food intake (42.7\%) in obese individuals following oxyntomodulin and PYY (3-36) administration was also observed, indicating an additive effect of both hormones [65].

\section{Gastrointestinal hormones affecting the secretion of insulin (incretin)}

The incretin effect involves meal-induced stimulation of insulin secretion. The effect was observed when insulin secretion increased more after oral glucose administration than after the intravenous infusion of an equivalent glucose dose, while maintaining stable plasma glucose levels [66]. Incretins are gastrointestinal hormones increasing postprandial insulin secretion by $\beta$-cells in the islets of Langerhans. Incretin hormones include:

1) glucagon-like peptide-1 (GLP-1),

2) glucose-dependent insulinotropic polypeptide (GIP); previous name: gastric inhibitory polypeptide.

\section{Glucagon-like peptide-1}

Glucagon-like peptide-1 (GLP-1) is encoded by a gene producing preproglucagon - a 160 amino acid fragment post-translationally generating the following peptides: GLP-1, GLP-2, glucagon, glicentin and OXM, depending on the site of expression, i.e. pancreatic $\alpha$-cells, intestinal L-cells or the central nervous system $[67,68]$ (Figure 4). 


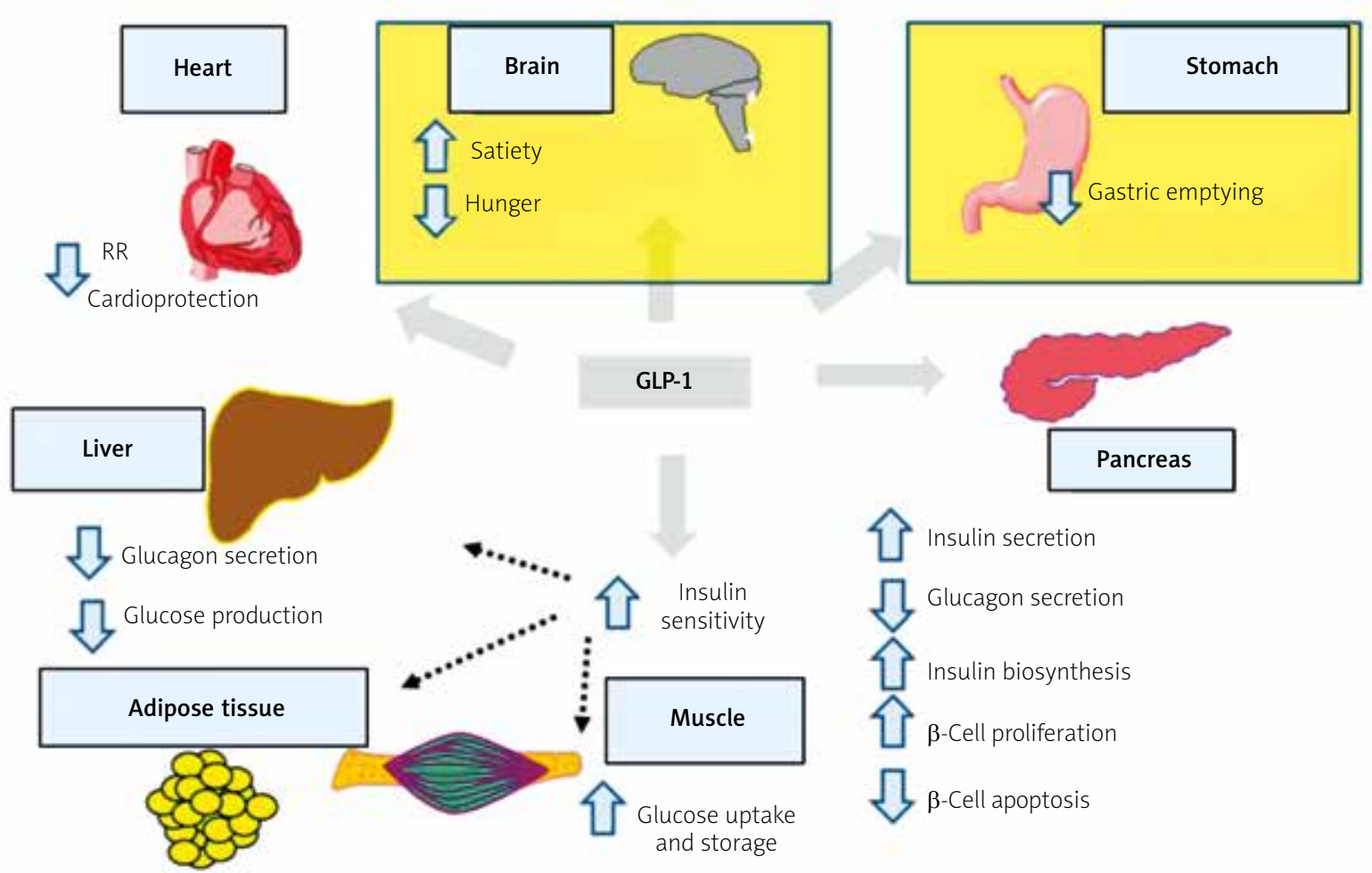

Figure 5. The main effects of GLP-1 actions (based on Baggio, Drucker, Gastroenterology 2007) [72]

Glucagon-like peptide-1 is mainly synthesized by L-cells in the duodenum, small and large intestine, and less by the pancreas and the hypothalamus. Its secretion in the gastrointestinal tract is influenced by glucose and fatty acids after food ingestion or as a result of vagus nerve stimulation. In peripheral circulation, GLP-1 has a very short half-life $\left(T_{1 / 2}=1-2 \mathrm{~min}\right)$ due to degradation of the active form (7-36) into inactive form (9-36) after disconnection of 2 terminal amino acids by dipeptidyl peptidase-4 (DPP-4) [70, 71].

The GLP-1 main mechanisms of action involve stimulating insulin secretion by $\beta$-cells in the islets of Langerhans and inhibiting glucagon secretion by $\alpha$-cells (Figure 5). Increased insulin secretion is the result of its increased synthesis. Substantial evidence exists to prove that the native GLP- 1 increases $\beta$-cell mass and inhibits their apoptosis [72]. Glucagon-like peptide-1, via the GLP-1 receptor in the central nervous system, shows also central effects, suppressing appetite and reducing the rate of food absorption into the blood by lowering the rate of gastric emptying [72-74]. Glucagon-like peptide-1 secretion depends on meal composition, and higher concentrations are observed after high-fat meals [75] (Figure 5).

\section{Glucose-dependent insulinotropic polypeptide}

Glucose-dependent insulinotropic polypeptide (GIP) is a 42 amino acid peptide secreted by $\mathrm{K}$ cells in the mucosa of the duodenum, jejunum and the proximal portion of the ileum. Both GIP and GLP-1 show incretin activity - stimulating food intake mediated insulin secretion by $\beta$-cells in the islets of Langerhans $[72,76]$. Postprandial GIP levels depend on the basic nutrient content of a meal. Higher values are observed after the ingestion of carbohydrates, compared with proteins [77].

Glucose-dependent insulinotropic polypeptide receptors are found not only in $\beta$-cells in the islets of Langerhans, but also in the adipose tissue, the central nervous system, the heart, the adrenal cortex and on the vascular endothelium. Additionally, GIP stimulates D-cells in the pancreatic islets to secrete somatostatins [72, 78, 79] and glucagon [80]. Both GIP and GLP-1 are rapidly ( $T_{1 / 2} \approx 2 \mathrm{~min}$ ) degraded by dipeptidyl peptidase-4 [71]. Resistance to GIP is observed in diabetic patients, which may be caused by a defect at the receptor level $[81,82]$. 


\section{Conclusions}

Recent studies indicate an important role of gastrointestinal hormones in appetite and satiety regulation. Evidence exists to prove that brain-gut axis disorders result in excessive energy accumulation and development of overweight and obesity. Peptides released from the gastrointestinal tract affect the activity of the hypothalamus and brain stem, both involved in food intake regulation and food habit modulation. Applying the knowledge of the brain-gut axis mechanism of action and implementing the data on physiological bases of food intake regulation in clinical practice may allow for more effective management of the obesity epidemic.

\section{References}

1. Bray GA. Autonomic and endocrine factors in the regulation of food intake. Brain Res Bull 1985; 14: 505-10.

2. Das UN. Obesity: genes, brain, gut, and environment. Nutrition 2010; 26: 459-73.

3. Lenard NR, Berthoud HR. Central and peripheral regulation of food intake and physical activity: pathways and genes. Obesity (Silver Spring) 2008; 16 (Suppl. 3): S11-22.

4. Coll AP, Faroogi IS, O'Rahilly S. The hormonal control of food intake. Nutrition 2007; 20: 251-62.

5. King BM. The rise, fall, and resurrection of the ventromedial hypothalamus in the regulation of feeding behavior and body weight. Physiol Behav 2006; 87: 221-44.

6. Suzuki K, Simpson KA, Minnion JS, et al. The role of gut hormones and the hypothalamus in appetite regulation. Endocr I 2010; 57: 359-72.

7. Kojima M, Hosoda H, Date Y. Ghrelin is a growth hormone releasing acylated peptide from stomach. Nature 1999; 402: 656-60.

8. Wren AM, Small CJ, Ward HL, et al. The novel hypothalamic peptide ghrelin stimulates food intake and growth hormone secretion. Endocrinology 2000; 141: 4325-8.

9. Cummings DE, Weigle DS, Frayo RS, et al. Plasma ghrelin levels after diet-induced weight loss or gastric bypass surgery. N Engl J Med 2002; 346: 1623-30.

10. Callahan HS, Cummings DE, Pepe MS, et al. Postprandial suppression of plasma ghrelin level is proportional to ingested caloric load but does not predict intermeal interval in humans. J Clin Endocrinol Metab 2004; 89: 1319-24.

11. Foster-Schubert KE, Overduin J, Prudom CE, et al. Acyl and total ghrelin are suppressed strongly by ingested proteins, weakly by lipids, and biphasically by carbohydrates. J Clin Endocrinol Metab 2008; 93: 1971-9.

12. Stock S, Leichner P, Wong AC, et al. Ghrelin, peptide YY, glucose-dependent insulinotropic polypeptide, and hunger responses to a mixed meal in anorexic, obese, and control female adolescents. J Clin Endocrinol Metab 2005; 90: 2161-8.

13. Korek E, Krauss H, Gibas-Dorna M, et al. Fasting and postprandial levels of ghrelin, leptin and insulin in lean, obese and anorexic subjects. Prz Gastroenterol 2013; 8: 383-9.
14. Mittelman SD, Klier K, Braun S, et al. Obese adolescents show impaired meal responses of the appetite-regulating hormones ghrelin and PYY. Obesity (Silver Spring) 2010; 18: 918-25.

15. Muccioli G, Tschöp M, Papotti M, et al. Neuroendocrine and peripheral activities of ghrelin: implications in metabolism and obesity. Eur J Pharmacol 2002; 440: 235-54.

16. Briggs DI, Andrews ZB. Metabolic status regulates ghrelin function on energy homeostasis. Neuroendocrinology 2011; 93: 48-57.

17. Andrews ZB, Liu ZW, Walllingford N, et al. UCP2 mediates ghrelin's action on NPY/AGRP neurons by lowering free radicals. Nature 2008; 454: 846-51.

18. Shearman LP, Wang SP, Helmling S, et al. Ghrelin neutralization by a ribonucleic acid-SPM ameliorates obesity in diet-induced obese mice. Endocrinology 2006; 147: 1517-26.

19. Wren AM, Small CJ, Abbott CR, et al. Ghrelin causes hyperphagia and obesity in rats. Diabetes 2001; 50: 2540-7.

20. Gibbs J, Young RC, Smith GP. Cholecystokinin decreases food intake in rats. J Comp Physiol Psychol 1973; 84: 488-95.

21. Buffa R, Solcia E, Go VL. Immunohistochemical identification of the cholecystokinin cell in the intestinal mucosa. Gastroenterology 1976; 70: 528-32.

22. Liddle RA, Goldfine ID, Rosen MS, et al. Cholecystokinin bioactivity in human plasma. Molecular forms, responses to feeding, and relationship to gallbladder contraction. J Clin Invest 1985; 75: 1144-52.

23. Moran TH, McHugh PR. Cholecystokinin suppresses food intake by inhibiting gastric emptying. Am J Physiol 1982; 242: 491-7.

24. Rehfeld JF, Sun G, Christensen T, et al. The predominant cholecystokinin in human plasma and intestine is cholecystokinin-33. J Clin Endocrinol Metab 2001; 86: 251-8.

25. Beinfeld MC, Meyer DK, Brownstein MJ. Cholecystokinin in the central nervous system. Peptides. 1981; 2 (Suppl. 2): 77-9.

26. Moran TH, Robinson PH, Goldrich MS, et al. Two brain cholecystokinin receptors: implications for behavioral actions. Brain Res 1986; 362: 175-9.

27. Wank SA, Pisegna JR, de Weerth A. Brain and gastrointestinal cholecystokinin receptor family: structure and functional expression. Proc Natl Acad Sci USA 1992; 89: 8691-5.

28. Melville LD, Smith GP, Gibbs J. Devazepide antagonizes the inhibitory effect of cholecystokinin on intake in sham-feeding rats. Pharmacol Biochem Behav 1992; 43: 975-7.

29. Moran TH, Katz LF, Plata-Salaman CR, et al. Disordered food intake and obesity in rats lacking cholecystokinin A receptors. Am J Physiol 1998; 274: R618-25.

30. Kopin AS, Mathes WF, McBride EW, et al. The cholecystokinin-A receptor mediates inhibition of food intake yet is not essential for the maintenance of body weight. J Clin Invest 1999; 103: 383-91.

31. Kissileff HR, Pi-Sunyer FX, Thornton J, et al. C-terminal octapeptide of cholecystokinin decreases food intake in man. Am J Clin Nutr 1981; 34: 154-60.

32. Smith GP, Jerome C, Cushin BJ, et al. Abdominal vagotomy blocks the satiety effect of cholecystokinin in the rat. Science 1981; 213: 1036-7.

33. Deutsch JA, Hardy WT. Cholecystokinin produces bait shyness in rats. Nature 1977; 266: 196 
34. Swerdlow NR, van der Kooy D, Koob GF, et al. Cholecystokinin produces conditioned place-aversions, not place-preferences, in food-deprived rats: evidence against involvement in satiety. Life Sci 1983; 32: 2087-93.

35. Mosher JT, Birkemo LS, Johnson MF, et al. Sulfated cholecystokinin (26-33) induces mild taste aversion conditioning in rats when administered by three different routes. Peptides 1998; 19: 849-57.

36. West DB, Greenwood MR, Marshall KA, et al. Lithium chloride, cholecystokinin and meal patterns: evidence that cholecystokinin suppresses meal size in rats without causing malaise. Appetite 1987; 8: 221-7.

37. Matson CA, Ritter RC. Long-term CCK-leptin synergy suggests a role for CCK in the regulation of body weight. Am J Physiol 1999; 276: R1038-45.

38. West DB, Fey D, Woods SC. Cholecystokinin persistently suppresses meal size but not food intake in free-feeding rats. Am J Physiol 1984; 246: R776-87.

39. Crawley JN, Beinfeld MC. Rapid development of tolerance to the behavioural actions of cholecystokinin. Nature 1983; 302: 703-6.

40. Zwirska-Korczala K, Konturek SJ, Sodowski M, et al. Basal and postprandial plasma levels of PYY, ghrelin, cholecystokinin, gastrin and insulin in women with moderate and morbid obesity and metabolic syndrome. J Physiol Pharmacol 2007; 58 (Suppl. 1): 13-35.

41. Schneeman BO, Burton-Freeman B, Davis P. Incorporating dairy foods into low and high fat diets increases the postprandial cholecystokinin response in men and women. J Nutr 2003; 133 : 4124-8.

42. Adrian TE, Ferri GL, Bacarese-Hamilton AJ, et al. Human distribution and release of a putative new gut hormone, peptide YY. Gastroenterology 1985; 89: 1070-7.

43. Eberlein GA, Eysselein VE, Schaeffer M, et al. A new molecular form of PYY: structural characterization of human PYY(3-36) and PYY(1-36). Peptides 1989; 10: 797-803.

44. Batterham RL, Cowley MA, Small C), et al. Gut hormone PYY(336) physiologically inhibits food intake. Nature 2002; 418: 650-4.

45. Batterham RL, Cohen MA, Ellis SM, et al. Inhibition of food intake in obese subjects by peptide YY3-36. N Engl J Med 2003; 349: 941-8.

46. El Khoury D, El-Rassi R, Azar S, et al. Postprandial ghrelin and PYY responses of male subjects on low carbohydrate meals to varied balancing proportions of proteins and fats. Eur J Nutr 2010; 49: 493-500.

47. Asakawa A, Inui A, Yuzuriha $\mathrm{H}$, et al. Characterization of the effects of pancreatic polypeptide in the regulation of energy balance. Gastroenterology 2003; 124: 1325-36.

48. Parker RM, Herzog H. Regional distribution of Y-receptor subtype mRNAs in rat brain. Eur J Neurosci 1999; 11: 1431-48.

49. Whitcomb DC, Taylor IL, Vigna SR. Characterization of saturable binding sites for circulating pancreatic polypeptide in rat brain. Am J Physiol 1990; 259: G687-91.

50. Kanatani A, Mashiko S, Murai N, et al. Role of the Y1 receptor in the regulation of neuropeptide $Y$-mediated feeding comparison of wild-type, $Y 1$ receptor-deficient, and $Y 5$ receptor-deficient mice. Endocrinology 2000; 141: 1011-6.
51. Flynn MC, Turrin NP, Plata-Salamán CR, et al. Feeding response to neuropeptide Y-related compounds in rats treated with Y5 receptor antisense or sense phosphothio-oligodeoxynucleotide. Physiol Behav 1999; 66: 881-4.

52. Schmidt PT, Näslund E, Grybäck P, et al. A role for pancreatic polypeptide in the regulation of gastric emptying and shortterm metabolic control. J Clin Endocrinol Metab 2005; 90: 5241-6.

53. Jesudason DR, Monteiro MP, McGowan BM, et al. Low-dose pancreatic polypeptide inhibits food intake in man. Br J Nutr 2007; 97: 426-9.

54. Batterham RL, Le Roux CW, Cohen MA, et al. Pancreatic polypeptide reduces appetite and food intake in humans. J Clin Endocrinol Metab 2003; 88: 3989-92.

55. Clark JT, Kalra PS, Crowley WR, et al. Neuropeptide $Y$ and human pancreatic polypeptide stimulate feeding behavior in rats. Endocrinology 1984; 115: 427-9.

56. Malaisse-Lagae F, Carpentier JL, Patel YC, et al. Pancreatic polypeptide: a possible role in the regulation of food intake in the mouse. Hypothesis Experientia 1977; 33: 915-7.

57. Bataille D, Coudray AM, Carlqvist $M$, et al. Isolation of glucagon-37 (bioactive enteroglucagon/oxyntomodulin) from porcine jejuno-ileum. Isolation of the peptide. FEBS Lett 1982; 146: 73-8.

58. Bataille D, Gespach C, Tatemoto K, et al. Bioactive enteroglucagon (oxyntomodulin): present knowledge on its chemical structure and its biological activities. Peptides 1981; 2 (Suppl. 2): 41-4.

59. Fehmann HC, Jiang J, Schweinfurth J, et al. Stable expression of the rat GLP-I receptor in $\mathrm{CHO}$ cells: activation and binding characteristics utilizing GLP-I(7-36)-amide, oxyntomodulin, exendin-4, and exendin (9-39). Peptides 1994; 15: 453-6.

60. Druce MR, Minnion JS, Field BC, et al. Investigation of structure-activity relationships of Oxyntomodulin (Oxm) using Oxm analogs. Endocrinology 2009; 150: 1712-22.

61. Schjoldager BT, Baldissera FG, Mortensen PE, et al. Oxyntomodulin: a potential hormone from the distal gut. Pharmacokinetics and effects on gastric acid and insulin secretion in man. Eur J Clin Invest 1988; 18: 499-503.

62. Cohen MA, Ellis SM, Le Roux CW, et al. Oxyntomodulin suppresses appetite and reduces food intake in humans. J Clin Endocrinol Metab 2003; 88: 4696-701.

63. Wynne K, Park AJ, Small CJ, et al. Subcutaneous oxyntomodulin reduces body weight in overweight and obese subjects: a double-blind, randomized, controlled trial. Diabetes 2005; 54: 2390-5.

64. Wynne K, Park AJ, Small CJ, et al. Oxyntomodulin increases energy expenditure in addition to decreasing energy intake in overweight and obese humans: a randomised controlled trial. Int J Obes (Lond) 2006; 30: 1729-36.

65. Field BC, Wren AM, Peters V, et al. PYY3-36 and oxyntomodulin can be additive in their effect on food intake in overweight and obese humans. Diabetes 2010; 59: 1635-9.

66. Holst JJ, Gromada J. Role of incretin hormones in the regulation of insulin secretion in diabetic and nondiabetic humans. Am J Physiol Endocrinol Metab 2004; 287: 199-206.

67. Kreymann B, Williams G, Ghatei MA, et al. Glucagon-like peptide-1 7-36: a physiological incretin in man. Lancet 1987; 5: $1300-4$ 
68. Gautier JF, Choukem SP, Gerard J. Physiology of incretins (GIP and GLP-1) and abnormalities in type 2 diabetes. Diabetes Metab 2008; 34: 65-72.

69. Kieffer TJ, Habener JF. The glucagon-like peptides. Endocr Rev 1999; 20: 876-913.

70. Elliott RM, Morgan LM, Tredger JA, et al. Glucagon-like peptide-1 (7-36)amide and glucose-dependent insulinotropic polypeptide secretion in response to nutrient ingestion in man: acute post-prandial and 24-h secretion patterns. J Endocrinol 1993; 138: 159-66.

71. Kieffer TJ, McIntosh CH, Pederson RA. Degradation of glucose-dependent insulinotropic polypeptide and truncated glucagon-like peptide 1 in vitro and in vivo by dipeptidyl peptidase IV. Endocrinology 1995; 136: 3585-96.

72. Baggio LL, Drucker DJ. Biology of incretins: GLP-1 and GIP. Gastroenterology 2007; 132: 2131-57.

73. D'Alessio DA, Sandoval Da, Salley RJ. New ways in which GLP1 can regulate glucosae homeostasis. J Clin Invest 2000; 115: 3406-8.

74. Kanoski SE, Fortin SM, Arnold M, et al. Peripheral and central GLP-1 receptor populations mediate the anorectic effects of peripherally administered GLP-1 receptor agonists, liraglutide and exendin-4. Endocrinology 2011; 152: 3103-12.

75. Maffeis C, Surano MG, Cordioli S, et al. High-fat vs. a moderate-fat meal in obese boys: nutrient balance, appetite, and gastrointestinal hormone changes. Obesity 2010; 18: 449-55.

76. Choukem SP, Gerard J. Physiology of incretins (GIP and GLP-1) and abnormalities in type 2 diabetes. Diabetes Metab 2008; 34: 65-72.

77. Karamanlis A, Chaikomin R, Doran S, et al. Effects of protein on glycemic and incretin responses and gastric emptying after oral glucose in healthy subjects. Am J Clin Nutr 2007; 86: 1364-8.

78. UsdinTB, Mezey E, Button DC, et al. Gastric inhibitory polypeptide receptor, a member of the secretin-vasoactive intestinal peptide receptor family, is widely distributed in peripheral organs and the brain. Endocrinology 1993; 133: 2861-70.

79. McIntosh CH, Pederson RA, Koop H, et al. Gastric inhibitory polypeptide stimulated secretion of somatostatinlike immunoreactivity from the stomach: inhibition by acetylcholine or vagal stimulation. Can J Physiol Pharmacol 1981; 59: 468-72.

80. Meier JJ, Gallwitz B, Siepmann N, et al. Gastric inhibitory polypeptide (GIP) dose-dependently stimulates glucagon secretion in healthy human subjects at euglycaemia. Diabetologia 2003; 46: 798-801.

81. Lynn FC, Pamir N, Ng EH, et al. Defective glucose-dependent insulinotropic polypeptide receptor expression in diabetic fatty Zucker rats. Diabetes 2001; 50: 1004-11.

82. Gupta D, Peshavaria M, Monga N, et al. Physiologic and pharmacologic modulation of glucose-dependent insulinotropic polypeptide (GIP) receptor expression in beta-cells by peroxisome proliferator-activated receptor (PPAR)-gamma signaling: possible mechanism for the GIP resistance in type 2 diabetes. Diabetes 2010; 59: 1445-50.

Received: 16.11 .2011

Accepted: 10.04 .2012 